\title{
PELAKSANAAN PENGENALAN KONSEP DASAR MATEMATIKA MELALUI METODE BERCERITA DENGAN MEMANFAATKAN LINGKUNGAN SEBAGAI SUMBER BELAJAR DI PAUD TERPADU NURAINI AISYIYAH YOGYAKARTA
}

\author{
Febritesna Nuraini \\ Fakultas Pendidikan Anak Usia Dini FKIP UAD \\ febritesna@gmail.com
}

\begin{abstract}
ABSTRAK
Penelitian ini bertujuan untuk menggambarkan pelaksanaan pengenalan konsep dasar matematika melalalui metode bercerita dengan memanfaatkan lingkungan sebagai sumber pembelajaran di PAUD Terpadu Aisyiyah Nuraini Kota Yogyakarta.Penelitian dilakukan dengan metode kualitaif. Data dikumpulkan dengan menggunakan interview, observasi, dan dokumentasi.Karakteristik subyek dalam penelitian ini adalah peserta didik usia 4- 5 tahun. Hasil Penelitian ini menunjukan bahwa dalam pelaksanaan konsep dasar matematika melalui metode bercerita peserta didik lebih mudah untuk memahami dan pendidik melaksanakan setiap pijakan sebelum belajar, hal ini disebabkan peserta didik lebih terpusat perhatiannya.
\end{abstract}

Kata kunci: Pendidikan anak usia dini, konsep dasar matematika, metode mendongeng

\begin{abstract}
:
The purpose of this study describethe implementation of the introduction ofthe basic concepts of mathematics through story telling method by utilizing the environmentas a sourceof learning in early childhood Aisyiyah Integrated Nuraini Yogyakarta. Qualitative research was conducted by the method. Data was collected using interviews, observations, and documentation. The characteristic subjects in this study were learners aged 4-5 years. The results of this study show that the implementation of the basic concepts of mathematics through story telling learners easier to understand and implement each foot hold before educator slearn, this is due to a more learner centered attention.
\end{abstract}

Key words: Early childhoodeducation, basicmathconcepts, methods ofstorytelling

\section{Pendahuluan}

Perkembangan anak usia dini berlangsung secara alamiah, dalam proses perkembangannya dan tidak lepas dari bantuan dari orang dewasa. Anak usia dini memiliki usia rentang waktu usia sejak lahir hingga enam tahun. Periode ini sering disebut sebagai peletak perkembangan dasar, karena perkembangan akan mempengaruhi perkembangan selanjutnya. Hurlock Menjelaskan (2000:26) menjelaskan usia pra sekolah adalah paling penting dalam seluruh tahapan perkembangan dan suatu analisis fungsional menjadi peletak dasar struktur perilaku kompleks yang dibangun sepanjang kehidupan anak. Data ini didukung dari hasil penelitian Bloom perkembangan intelektual anak 
usia dini mencapai $80 \%$ dan sisanya pada usia dewasa.

Kehidupan anak usia dini dengan berbagai pengaruh merupakan periode kehidupan yang sangat penting khususnya berkaitan dengan diterimanya rangsangan (stimulasi) dan perlakuan dari lingkungan sekitar. Stimulasi dalam Febritesna (2012:83) adalah pemberian rangsangan dan latihan-latihan terhadap kepandaian anak yang datangnya dari lingkungan luar anak. Pemberian ransangan (stimulasi) pada anak usia dini diberikan dengan sebaik-baiknya, dengan diberi perlakuan intervensi dari orang dewasa.

Dalam

membantu

tumbuhkembangan anak, pemerintah mendirikan pendidikan anak usia dini (PAUD). Pendidikan anak usia dini menurut Undang-Undang No 20 Tahun 2003 Tentang Sistem Pendidikan Nasional menyatakan bahwa PAUD adalah suatu upaya pembinaan yang ditunjukan kepada anak sejak lahir sampai dengan usia 6 tahun yang dilakukan melalui pemberian ransangan pendidikan untuk membantu pertumbuhan dan perkembangan jasmani dan rohani agar anak memiliki kesiapan dalam memasuki pendidikan lanjut.

Pendidikan anak usia dini memiliki peranan penting dalam membantu tumbuhkembang anak usia dini. Sebagai peletak dasar pendidikan anak, pendidik anak usia dini memberikan pembelajaran sesuai dengan sifat unik anak. Pembelajaran yang diberikan saling berkoordinasi dengan tahapan perkembangan anak. Matematika adalah ilmu tentang bilangan-bilangan, hubungan antar bilangan dan prosedur operasional yang digunakan dalam penyelesaian persoalan mengenai bilangan (pusat pengembangan bahasa:1991). Matematika selama ini oleh peserta didik merupakan materi pembelajaran paling menyeramkan, sehingga banyak anak-anak kurang tertarik untuk mempelajarinya. Demikian dengan anak usia dini pengenalan konsep dasar matematika seharusnya sesuai dengan sifat unik anak, yaitu kegemaran anak untuk mendengarkan dongeng, Sehingga pendidik mampu mengintegrasikan kegemaran anak ke dalam pembelajaran anak usia dini sehingga membatu perkembangan anak.

Hasil observasi pada bulan Desember 2012 di TK PKK 27 Jambean Panjangan Kabupaten Bantul dan TK Pembina 1 Tembi Kabupaten Bantul masih ditemukan pembelajaran di TK masih berfokus pada kognisi dengan metode konvensional, seperti pembelajaran berhitung. Sehingga anak kurang difasilitasi untuk mengeksplorasi seluruh kemampuan yang 
dimilikinya.Selama ini pendidik PAUD khususnya Taman Kanak-kanak (TK) belum mengintegrasikan pembelajaran ke dalam seluruh tahapan perkembangan anak. Bercerita dengan memanfaatkan lingkungan sebagai sumber be;ajar belum digunakan sebagai metode untuk mengenalkan konsep dasar matematika.

Penelitian ini bertujuan untuk mendeskripsikan pengenalan konsep dasar matematika melalui metode bercerita dengan memanfaatkan lingkungan sebagai media sumber belajar, Faktor-faktor apa saja yang mempengaruhi dan Pemanfaatan lingkungan sebagai sumber belajar konsep dasar matematika. Hasil penelitian ini diharapkan dapat memudahkan guru di dalam mengajarkan pengenalan konsep dasar matematika pada anak usia dini.

\section{Metode Penelitian}

Penelitian ini menggunakan rancangan penelitian deskriftif kualitatif dengan jenis penelitian studi kasus, paling baik kalau disajikan dalam bentuk corong. Bogdan dan Biklen (1982) menjelaskkan bahwa awal studi adalah bagian corong yang lebar.Bentuk ini dianjurkan sebagai langkah sistematik penelitian.Mula-mula peneliti mengkaji tempat dan orang yang dapat dijadikan sumber data atau subyek penelitian, menentukan lokasi dan mengembangkan jaringan-jaringan untuk menemukan sumber data.

Teknik pengumpulan data dalam penelitian ini dilakukan melalui wawancara, pengamatan, dan dokumentasi. Subyek Penelitian ini adalah anak usia dini dengan usia 4-5 Tahun. Penelitian dilaksanakan di PAUD Terpadu Nuraini Aisyiyah Yogyakarta, mulai Bulan Februari sampai Agustus 2013.

Trianggulasi data dikerjakan dengan menggunakan lebih dari satu strategi penelitian untuk mempeoleh sebuah informasi yang sama. Ada tiga jenis strategi yang digunakan dalam mengumpulkan data penelitian sebagai berikut; wawancara, pengamatan peran serta dan dokumentasi. Hal ini dilakukan untuk menggali data dan informasi mengenai faktor-faktor anak usia dini yang mempengaruhi pembelajaran pengenalan konsep dasar matematika, pelaksanaan pengenalan konsep dasar matematika menggunakan metode bercerita dan Memanfaatkan lingkungan sebagai media sumber belajar.

Aanalisis data penelitian meliputi menata data, membagi satuansatuan, mensintesis, mencari pola, menemukan apa yang penting dan apa yang dipelajari untuk disajikan sebagai 
laporan. Hasil akhir penelitian ini berupa sajian pemaparan.

\section{Hasil Penelitian}

Hasil penelitian ini meliputi tiga hal, yaitu faktor-faktor anak usia dini yang mempengaruhi pembelajaran pengenalan konsep dasar matematika, pelaksanaan pengenalan konsep dasar matematika menggunakan metode bercerita dan Memanfaatkan lingkungan sebagai media sumber belajar. faktorfaktor anak usia dini yang mempengaruhi pembelajaran pengenalan konsep dasar matematika adalah sebagai berikut. Pertama dalah konsentrasi, kesulitan memusatkan perhatian, daya ingat dalam mengingat huruf, kata, bentuk ruang dan angka yang sudah ditulis dan yang belum ditulis.Anak usia dini sering memahami keberbalikan dalam mengidentifikasi angka, Misal Deretan angka 1,2,3,4, 5 dan ditulis 1,3,5. Ada beberapa peserta didik sering mengurutkan bangun ruang dengan sistem pengelompokan tidak berurutan, yaitu mulai dari yang besar, kecil dan kecil kembali, pada saat itu adalah kegiatan bermain meroncen dengan pola A B C. Ada 4 orang anak sulit mengingat urutan jumlah benda yang ditata dalam satu tempat gelas. Misalnya Mengurutkan sesuai jumlah, anak mengerjakan hitungan berloncat.
Kedua Pelaksanaan Pengenalan konsep dasar matematika menggunakan metode bercerita. Terkait dengan pelaksanaan pengenalan konsep dasar matematika diperoleh gambaran umum adalah sebagai berikut guru-guru dalam membangun cerita masih mengalami kendala, hal ini disebabkan karena akan membangun pemahaman kepada peserta didik dan mampu mmengaplikasikan secara mudah dan senang dalam kegitan bermain. Ketiga adalah memanfaatkan lingkungan sebagai sumber belajar, pendidik memiliki daya kreatifitas yang cukup tinggi dalam memanfaatkan sumber daya lingkungan seperti batu kerang, air dan jam bekas. Misalnya di sentra Persiapan Guru sentra menyipkan 8 (delapan) permainan dengan asumsi anak akan bermain 3-4 permainan. Pada hari itu tema kegitan pembelajaran adalah mengenai diri sendiri, guru memulaipijakan sebelum belajar dengan menggunakan jam bekas. Guru bercerita kegiatan setiap hari ku, sambil menggerakan waktu dengan mengajak peserta didik yang lainnya untuk berinteraksi membangun komunikasi efektif bersama. Peserta didik diajak menyebutkan bentuk atau bangun ruang yang guru bawa, seperti kotak, lingkaran ada anak yang menyebutkan bunder atau bulat kaya "endhok" . 


\section{Pembahasan}

Berdasarkan hasil penelitian ini menunjukan bahwa, faktor-faktor yang dihadapi anak usia dini dalam kegiatan pembelajaran adalah sulit konsentrasi, memusatkan perhatian, daya ingat dalam mengingat huruf, kata, angka dan bentuk. Dalam tulisan anak usia dini sering ada huruf, kata dan angka dalam suatu kalimat ditulis secara tidak secara berurutan, yatitu memulai dari angka yang tepat ada satu angka awal kemudian angka terakhir baru angka berikutnya dalam satu kegiatan. Aanak mengalami kesulitan menulis, mengurutkkan apabila kegiatan pembelajaran baru saja dimulai atau diucapkan oleh guru dan atau baru pertama kali pembelajaran didengan oleh peserta didik.

Peserta didik masih sering keliru sesuai dengan ucapan guru. Kegiatan belajar beraya bermain anak masih sering acak-acakan, karena tahapan perkembangan Praoperasional . Anak usia dini dalam teori Jean Piaget masih didalam tahapan perkembangan praoperasional, Dikatakan praoperasional karena pada tahap ini anak belum memahami pengertian operasional yaitu proses interaksi suatu aktivitas mental, dimana prosesnya bisa kembali pada titik awal berfikir secara logis.

Manipulasi simbol merupakan karakteristik esensial dari tahapan ini.
Hal ini sering dimanefestasikan dalam peniruan tertunda, tetapi perkembangan bahasanya sudah sangat pesat, kemampuan anak menggunakan gambar simbolik dalam berfikir, memecahkan masalah, dan aktivitas bermain kreatif akan meningkat lebih jauh dalam beberapa tahun berikutnya. Sekalipun demikian, pemikiran pada tahap praoperasional terbatas dalam beberapa hal penting. Menurut Piaget, pemikiran itu khas bersifat egosentris, anak pada tahap ini sulit membayangkan bagaimana segala sesuatunya tampak dari perspektif orang lain.

Pada umumnya dalam memberikan kegiatan belajar untuk anak usia dini lebih mengembangkan bagaimana guru melakukan pendekatan didalam kelas dengan berbagai metode, Pendidik lebih diajak mampu berkreasi, kreatif dan inovatif dalam menyampaikan pembelajaran dikelas. Membantu mengoptimalkan perkembangan anak PAUD Terpadu Nuraini Aisyiyah mengunkan kegiatan model sentra. Kegiatan model pembelajaran sentra pendidik/guru membangun konsep dan memberi 4 pijakan.Pijakan (scaffolding process) adalah dukungan yang berubahrubah yang disesuaikan dengan perkembangan untuk mencapai perkembangan lebih tinggi. Ada empat pijakan dalam model pembelajaran 
sentra yaitu: pijakan lingkungan bermain, pijakan sebelum bermain, pijakan selama bermain dan pijakan setelah bermain.

Kegiatan bercerita dilaksanakan di pijakan sebelum bermain dikegiatan ini peserta didik lebih diajak berinteraksi dengan guru. Guru Memulai dengan menanyakan tema dan kegiatan yang akan dipelajari. Guru atau pendidik melaksanakan kegiatan ini bercerita secara lansung tanpa menggunakan buku cerita, lebih berkreasi sendiri. Terkadang juga menggunakan buku cerita sebagai alat bantu. Guru sentra lebih mengedapan memanfaatkan lingkungan sebagai media sumber belajar karena lebih mudah memahamkan anak. Salah satu contonhya adalah jam bekas, guru bisa bercerita dengan jam bekas tersebut, mulai dari mengenal bangun ruang, angka dan membandingkan. Hal ini selaras dengan konsep dasar matemtika untuk anak usia dini menurut The principles and strandards for school mathematicsyang dikembangkan oleh NTCM (2000) masih memaparkan konsep bilangan, aljabar, penggolongan, membandingkan dan menyusun, pola, geometri/ bangun ruang, pengukuran dan analisis probabilitas. Kegiatan pembelajaran dilaksanakan dengan bermaian saat pijakan bermain, pendidikan menyediakan delapan permainan dan anak-anak menyelesaikan 3-4 permainan, seperti meronce, mengelompokan sesuai bentuk, menulis mengikuti jumlah dan menyebutkan bentuk bangun ruang.

\section{Kesimpulan}

Berdasalakan dari hasil pembahasan dan analisis data, di dapatkan kegitan penelitian mengenalkan konsep dasar matematika pada anak usia dini menjadi pemahaman tersendiri untuk pendidik. Tahapan perkembangan anak usia dini masih praoperasional dimana anak masih mengenal benda-benda secara nyata. Tingkat pemahamna peserta didik juga berbeda-beda karena dipengaruhi oleh faktor-faktor yang dibawa oleh anak.Bagaimana pendidik mamampu mengembangkan dan memimalisir kesalahan-kesalahan.Metode bercerita merupakan salah satu konsep metode yang dilaksanakan di PAUD Terpadu Nuraini Aisyiyah Yogyakarta.

\section{Pustaka}

Undang-Undang No 20 Tahun 2003, Tentang Sistem Pendidikan Nasional.

Hurlock.E.B. 1978.Child Development 6th Ed. Tokyo.Mcgraww Hill Inc. International Student Ed.

Richard P. Halgin. 2010. Psikologi Abnormal. (Terjemahan) Edisi 6. Salemba Humanika

Daniel P Hallan \& James M. Kauffman. Exceptional Children 
Introduction to special

Education, $4^{\text {th }}$, University of

Virginia.

Slamet Suyanto, 2005. Dasar - Dasar

Pendidikan Anak Usia Dini.

Yogyakarta:Hikayat

Kartono,kartini. 1985. Mengenal Dunia

Kanak-kanak.jakata . CV.

Rajawali

Lawrence, E.S. 1997. Mengarjakan

Emosianal Intelegence pada

Anak.Jakarta. Gramedia

J. W. Santrok Child Development 6th Ed.

Tokyo. Mcgraww Hill Inc.

International Student Ed.

Febritesna Nuraini.2012. Pemanfatan

Lingkungan

Untuk
Mengenalkan

konsep

Matematika Pada anak usia dini dengan menggunakan metode Mendongeng. Prosiding Pendidikan Matematika.

Depdikbud. 2007. Bidang Pengembangan Kognitif TK. Depdikbud:Jakarta Diana Mutiah, 2010. Psikologi Bermain Anak Usia Dini. Kencana Prenada Media Group: Jakarta. Muryani . 2010. Jurnal Pendidikan Penabur - No.15/Tahun ke9/Desember 2010

Milles \& Huberman. (1992). Analisis Data kualitatif (Terjemahan Tjetejep Roehadi). Universitas Indonesia Press:Jakarta 
